\title{
Identify Opportunities within the School Indoor Olympiad Project
}

\author{
Ali Yaghobi ${ }^{1}$ and Mohammad bagher Forghani Ozrudi ${ }^{2 *}$ \\ ${ }^{1}$ PhD Student of Sport Management, Islamic Azad University, Iran \\ ${ }^{2}$ Young Researchers and Elite Club, Azad University, Iran
}

*Corresponding author: Mohammad bagher Forghani Ozrudi, Young Researchers and Elite Club, Qaemshahr Branch, Islamic Azad University, Qaemshahr, Iran

Submission: 侮 March 13, 2018; Published: 监 August 06, 2018

\begin{abstract}
The object of this study is to identify opportunities within the school indoor Olympiad project in Mazandaran province. The study is of applicable one and has been done in fields. Statistical population includes 1517 teachers of physical education employed on mazandaran education and training in which statistical samples are selected 312 persons based on Morgan table. For data collection, the analysis of documents and literature were studied and a questionnaire survey using the Delphi method with 10 expert's meetings PE managers in Mazandaran province were responsible for the event were consulted. Information gathering instrument is certain questionnaire of opportunities of executing school indoor Olympiads by five measure likhert scales $(\alpha=0.89)$. We have used of freadmen and SPSS22 software in order to rank examined factors ( 6 opportunities). To hold indoor school sports Olympiad opportunities such as identity and physical education teachers, positive social behavior, assistance and participation of colleagues and parents for the Olympiad, motivation to exercise, athletic talent, strengthening and development of student's sports; develop a strategic plan and appropriate strategies to take advantage of the opportunities in the implementation of the school sports Olympiad is suggested.
\end{abstract}

Keywords: Sport olympiad; Opportunities; PE teachers; Mazandaran province

\section{Introduction}

Located in various development indicators is one of the most important sports [1]. Its sports with cultural phenomena, social, political and economic importance of this phenomenon and suggests its role in the national development plans of countries [2]. It is some decades in which sport role in society has been paid more attention of researchers. Because, physical education is a fixed element of education and training and also as recreation and amusement has influenced society $[3,4]$. Learning area physical education and health is one of eleven National Curriculum areas of learning to make healthy physical, mental and employing students as trustee of the divine right of physical activity, improve physical and motor skills, methods explanation Recreation and promoting health and healthy living and prevention of disease, disorder and organ disabilities and enabling people to maintain control over their behaviour and health [5].

Physical education and schools' sport is some part of educational experience and even life one and quality of this program has been maintained by correct programming [6]. One of activities in which grows basic skills and physical education in students is supra program activities in inner school Olympiads pattern. Extracurricular activities have provided required ground for students to pay attention to their interests and take step on dehiscence of their talents [7].
Researches have shown there is so many advantages by participating on doing extracurricular activities like physical education. A student who participates on extracurricular activities has shown more social adaptabilities [8,9]. So many studied has shown positive relation among participating on extracurricular activities and self-confidence [10-12]. Participating on extracurricular activities increases psych health in youth $[13,14]$. Extracurricular activities strengthen bodily, sensational, social, national, aesthetics and mental dimensions of children [15]. Recent studies have shown participating on extracurricular activities is related to the grounds like decreasing possibility of education cut in school specially on high school years, decreasing substance abuse and crimes, increasing inner personal competition and positive self-image and high mean and interaction to school, active participation on piltical procedure and other voluntarily activities, health and mental hygiene on adults [16].

Important parts of recreational activities and students extracurricular on physical education games in and out of school have been executed on so far years. Today's, inner school games, inner class and inner school's games has been executed on two types of multi fields (inner sport plympids and out of school) and one field (country athlete students) the first one by schools' physical education teachers and the other by education and training general office 
$[4,17]$. According to current costs of national design in province schools and perhaps without strategy in some aspects of affair, researchers recognize obstacles of general design of sport in mazandaran schools. At last, experts view and physical education teachers are the basic in developing country physical education and the basic factor in developing physical education in schools in which has been considered. When physical education program does have important shred in the youth health, knowing problems of national design of physical education in schools is required. Therefore, we should pay attention to physical education fields in province schools seriously. Multi-fields concentrated physical education games by the name of inner school's students' physical education Olympiads has been executed from 2014 among any school's students. Because if the start of any design, there is so many problems in which in some cases determined targets are not followed, sometimes even there is some contradictions in which transforms design. In this regard, we are discovering some existing opportunities in developing indoor schools Olympiads in order to understand is there any opportunities in developing indoor schools Olympiads in mazandaran or not?

\section{Materials and Methods}

This study according to the target is applicable and has been done by descriptive- qualified method. Information has been gathered in fields. Statistical population includes 1517 physical education teachers in which are working as official, contracting in edu- cation and training office of mazandaran in 52 cities. According to morgan Table, 512 teachers among these three regional's has answered questionnaire randomly. We have distributed 450 questionnaires according to statistical society after completing, 364 questionaiire has been gathered and among them 312 questionnaires have been considered and evaluated. Inner schools Olympiads executing opportunities questionnaire is certain questionnaire in which has been compiled as five scales likhert. This questionnaire in opportunity section has considered 6 indicators $(\alpha=0.89)$.

Gathered information has been described by descriptive statics methods including frequency, percentage, central tendency indicators, discrepancy, table, has been categorized and described. Also in inferential static sections, static data has been ranked based on freadmen test. Accounting has been done by SPSS $_{22}$ software on level $\mathrm{p} \leq 0.05$.

\section{Results}

According to the results on Table $1 \& 2$, we could say in opportunities of executing inner school Olympiads on mazandaran, teacher's identity giving chooser and physical education lesson does have the most importance in this section. Therefore, according to this result, we should make use of these opportunities for establishing physical education lesson on students and family. Also, strengthening and developing students' physical education does have the least importance from tested views.

Table1: Ranking executing opportunities of inner school Olympiads design (freadmen test).

\begin{tabular}{|c|c|c|c|c|c|}
\hline & Factor & Mean & SD & Mean Rank & Rank \\
\hline \multirow{6}{*}{ 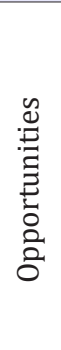 } & Teachers identity giving and physical education lesson & 25.33 & 5.59 & 5.54 & $1^{\text {st }}$ \\
\hline & social positive behaviours & 23.18 & 5.47 & 4.6 & $2^{\text {nd }}$ \\
\hline & $\begin{array}{l}\text { Cooperation and participation of cooperatives and parents on } \\
\text { executing olympiads }\end{array}$ & 4.59 & 6.43 & 4.59 & $3^{\text {th }}$ \\
\hline & Establishing motivation for physical activities & 19.14 & 3.82 & 3.25 & $4^{\text {th }}$ \\
\hline & Physical education talent seeking & 11.08 & 2.56 & 2.01 & $5^{\text {th }}$ \\
\hline & Strengthening and developing students physical education & 7.04 & 1.91 & 1.01 & $6^{\text {th }}$ \\
\hline
\end{tabular}

Table 2: Freadmen test for approving opportunities in executing indoor school Olympiads.

\begin{tabular}{|c|c|c|c|c|}
\hline Factor & N & K Square & Freedom Degree & Sig. \\
\hline $\begin{array}{c}\text { Olympiads executing challeng- } \\
\text { es }\end{array}$ & 312 & 839.47 & 5 & 0.001 \\
\hline
\end{tabular}

\section{Discussion and Conclusion}

As we see result of study, executing physical education Olympiads inner schools based on principal changes of education and training does have opportunities like teachers' identity giving and physical education lesson, positive social behavior, participation and cooperation of parents for executing Olympiads, creating motivation for physical activities, physical education talent seeking, strengthening and developing student physical education. Therefore, we should try to use of these opportunities at last. Current study result is the same as Razavi et al. [18], Shabanibahar et al. [19], Nikkho et al. [4], in teacher identity giving factor and physical education lesson. Identity giving to physical education lesson is only achievable on the shadow of codified and correct quality and programming. In positive behavior of students factor including decreasing crimes and on the other hand strengthening bravely mode and athletic teaching, current study result are the same as researchers like Sajjadi et al. [20], Hajizade et al. [21], Mc Mahon \& Belur [22], Kalashi et al. [3], Nazari et al. [23], Ehsani et al. [24], Ziapour \& Kianipour [25], Machin et al. [26], Jones Palm \& Palm [27], Morris et al. [28], Pate et al. [29] about decreasing crimes. based on result has been achieved of this study, un-normal behavior among students participated on physical education activities like inner school Olympiads and recreational times is less than non-active students in these activities. 
Therefore, people participation on physical education and physical activities could help them on having correct style of living and at last leads to creating and maintaining health society. therefore, by exact programming and using family participation, we could make culture of activities like recreational times and inner school Olympiads and put physical education in life style to support and encourage them and decrease crimes in school level and at last on society level. The result of this study is not the same as Ebrahimi [30]. He has found physical education except on smoking regard does not have preventive aspect of anti-social behaviours and could show existing of influential factors on family and society for person affected by antisocial behaviours. By these influential factors, physical education does have the least share on non-affecting youth to anti-social behaviours.

On the other hand, strengthening athletic mode and bravely teaching are the signs of positive social behaviours, current study result is the same as the result of Morsaei \& Naghdali [31], Nikkho et al. [4], Shajie et al. [24], Stornes [32], Vallerand et al. [33], has found a system could encourage athletic mode in which their owners have been trained on this view and has been grown up. On this case, simple education, creative and nowadays athletic values along with emphasis and investing on decision makers institute and high level could be the ground for increasing mental recognition and cultural of athletes on the long run. Vallerand et al. [33] has found on their study, by establishing feasible environment in physical education games, we could strengthen bravely mode among athletes. Stornes [32] has found observed behavior on the ground by athletes specially about respecting responsible, rules and rivals, shop was low level of sport mode. their study has shown trainers are the basic influential factors especially for youth in the ground of bravely mode tendency. Also, condition and social grounds are influential on people tendency to athletic mode. Also, Morsaei \& Naghdali [31] has found scientific using of physical education games for institutiating and fixing beliefs and students mentality are the basic aims of country, could be paid attention on extracurricular program pattern (like inner school olympids) now and on futureon educational pillars on schools and responsible for now and future.

About cooperation and participation of cooperatives and parents for executing olympids and creating motivation for physical education activities, the result of Nikkho et al. [4] has shown whole participation of responsible, teachers, families and students has his own their importance correctly. By giving responsibilities to people on executing inner school Olympiads and motivating them for doing physical activities and correct programming, the importance of games and sport and physical education and its role on social and personal health of students to families and to the students has been approved and for them physical education is one of happy environmental factors and its influence on education and student learning has been posited. About talent seeking in physical education, are the same as Mehrpour et al. [34], Abdimoghaddam et al. [35], Zabihi et al. [36], Nikkho et al. [4] on physical education talent seeking. Without doubt, we could program correctly on the ground of regional sports and improve understanding skills and train sport talents, and these could be achieved by executing codified talent seeking procedure on the ground of inner school Olympiads in which training, regional games are the parts of games on all educational level [37].

\section{References}

1. Sotiriadou P (2013) Sport development planning: the sunny golf club. Sport Management Review 16(4): 514-523.

2. Gharakhanlo R, Alizadeh MH (2000) Consider how leisure Veterans and Disabled with emphasis on the role of physical education and sport. Journal of motion 2(2): 39-42.

3. Kalashi M, Hoseini SE, Ebrahimipour T, Yamini M (2014) Determining the role of sport and physical activity in establishing health society by emphasize on decreasing crimes and substance abuse. The first national and expert conference of physical education association and Irans' sport science. Shahid Beheshti University, Iran.

4. Nikkhoo M, Mohammadi N, Barari AR (2015) Relationship indoor school sports Olympiad with achieve the objectives of fundamental transformation document Ministry of Education. International Journal of Sport Studies 5(7): 890-894.

5. Afzalpour ME, Zerang M, Khoshbakhti J (2007) Evaluating the implementation of physical education in first and second grades of primary schools in South Khorasan. Research in Sport Sciences. 55: 107125.

6. Sajjadi SA, Razavi SMH, Mohamadi A (2015ํㅡㄹ The compare of teacher viewpoints about the factors effecting on quality of physical education course. $8^{\text {th }}$ International Congress on Physical Education \& Sport Sciences. Teharn, Iran.

7. Imamjom'e SM, Ahmadi G, Teimournis M (2013) Examining exctracurricular comparative activities on elementary schools of Iran to U.S, ENGLISH and MALESIA countries, lesson program studies 3(1): $17-65$.

8. Barati A, Zandi P (2010) Determining the influence of extracurricular activities on educational progress of students. Research council of Tehran general council in AP study design.

9. Smitht PH (2007) The relationship between scores on the Bell Adjustment Inventory and participation in extra-curricular activities.

10. Farhadi S (2004) Determining the influence of activity on students' council on self-esteem and responsibility taking of guidance school students on Karaj. Master degree thesis.

11. Kazemi M (2008) Examining the influence of extracurricular activities on the amount of girl and boy students' responsibilities taking on Damavand high schools. Master degree thesis, Azad University of Roodehen, Iran.

12. Blomfield CJ, Barber BL (2009) Australian adolescent extracurricular activity participation and self- concept. J Adolesc 32(3): 733-739.

13. Meyers J, Perez L (2004) Structured extracurricular activities among adolescents. University of Kentucky, USA.

14. Kerr B (2009) Encyclopedia of giftedness, creativity, and talent. A SAGE Reference Publication.

15. Adams GN, Shea C (2008) Learning to teach a critical approach to field experiences, Publishers Mahwah, New Jersey, USA.

16. Pkins S (2008) Non-School curriculum supporting positive development through structured activities. SAGE Publication.

17. Amirtash AM (2010) Describing and evaluating fifth physical education Olympiads of country universities, research report, physical education research institute and sport science of science ministry, research and technology. 
18. Razavi SMH, Shabanibahar GR, Sajjadi SA (2011) Analyzing influential factors on the quality of physical education esson in guidance schools from physical education teachers' view. Sport management research magazine and movement behavior 7(4): 103-113.

19. Shabanibahar GR, Erfani N, Ashraghi A (2008) Examining influential factors on the quality of physical education lesson in high schools from physical education view 5(3): 143-156.

20. Sajjadi SA, Razavi SMH, Chavoshi M, Forghani MR (2015b) Role of physical education on the procedure of preventing crimes of physical education and sport science. Shahid Beheshti University, Tehran, Iran.

21. Hajizade S, Naderian Jahromi M, Soleimani M (2015) Ranking influential social factors on physical education participation of students. Fourth national conference of university students in physical education fileds of Shahid Beheshti University, Iran.

22. McMahon S, Belur J (2013) Sports-based Programmes and Reducing Youth Violence and Crime. Project Oracle synthesis study.

23. Nazari N, Niromand S, Ghafoori F (2014) Role of physical education activities on recreational times in in normal behaviours of boy students in high schools on Tehran. The first scientific and expert conference of physical education association and Iran physical education science, Shahid Beheshti University, Tehran.

24. Shajie R, Kozechian H, Ehsani H, Amiri M (2013) Examining athletic nature situation in Irans' soccer athletic players, new approaches in physical education management 1(2): 69-82.

25. Ziapour A, Kianipour N (2012) Influence of participation patterns in physical education activities (experimental study of Kermanshah Islamic Azad University) youth study sociology seasonal magazine 3(6): 91-108.

26. Machin S, Marie O, Vujić S (2010) The crime reducing effect of education. Centre for Economic Performance, London School of Economics and Political Science.

27. Jones Palm DH, Palm J (2004) Physical activity \& its impact on health behavior among youth Teens in sports live healthier lifestyles.

28. Morris L, Sally banks J, Willis K (2003) Sport, physical activity and antisocial behaviour in youth, Research and Public Policy Series, no. 49, Australian Institute of Criminology, Canberra, Australia.
29. Pate R, Heath W, Dowda M, Trost G (1996) Associations between physical activity and other health behaviors in a representative sample of US adolescents. Am J Public Health 86(11): 1577-1581.

30. Ebrahimi SJ (2011) Eomparing the method of spending recreational times and crimes in the athlet youth and non athletes. Master degree thesis, allame Tabatabee University, psychology and training science college.

31. Morsaei M, Naghdali A (2015) Describing the method of profiting mentally from attractive opportunities of Olympiads inner school. fourth national Olympiads of university students on Shahid Beheshti University physical education science, Iran.

32. Stornes T (2001) Sportsperson ship in elite sports: On the effects of personal and environmental factors on the display of sportspersonship among elite male handball players. European Physical Education Review $7(3): 283-304$.

33. Vallerand RJ, Briere NM, Blanchard C, Provencher P (1997) Development and validation of the multidimensional sportsperson ship orientation scale. Journal of Sport and Exercise Psychology 19(1): 197-206.

34. Mehrpour AA, Hajizade K, Haghizade H (2013) Importance of executing training games in the procedure of physical education talent seeking, third national conference of physical education talent seeking. Tehran, Iran.

35. Abdimoghaddam S, Ghotbi M, Ahmadzade Z (2013) Influence of national regional games on understanding form and children ground from 7 to 10 years old. Third national conference of physical education talent seeking. Tehran, Iran.

36. Zabihi S, Ashouri M, Ghaffari S (2013) Providing approaches for training and discovering talents in tanavarz design among trainers and Fars teachers. Third national conference of physical education talent seeking, Tehran, Iran.

37. Caswell SV, Cortes N, Chabolla M, Ambegaonkar JP, Caswell AM (2015) State-specific differences in school sports preparticipation physical evaluation policies. Pediatrics 135(1): 26-32.
Creative Commons Attribution 4.0

International License

For possible submissions Click Here
Submit Article

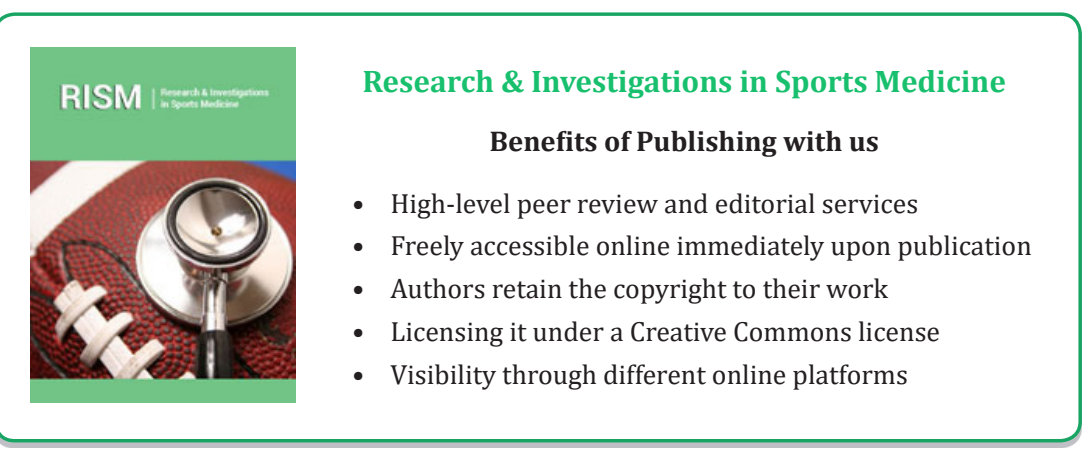

